\title{
THE STRUCTURAL AND SPATIAL POSITION OF SUFISM WITHIN ISLAM IN BOSNIA AND HERZEGOVINA
}

\author{
Jurica Botić*1 \\ "Ministry of Science and Education, Zagreb, Croatia
}

\begin{abstract}
The article introductorily presents the terminological and dogmatic determinants of Sufism as one of the ways of practicing Islam. The basic aim of this article is to determine the position of Sufism and the dervish orders within religious structures and spatial distribution of Islam in Bosnia and Herzegovina in correlation with the religious and national identity of Bosniaks. In fact, using the method of historical analysis, the article seeks to clarify the position and significance of Sufism and dervish orders in Islamic religious tradition in Bosnia and Herzegovina and their contribution to the development of urban systems in this country. The article also emphasizes the role and significance of the renewal of the dervish orders in the Bosnian-Herzegovinian society as part of the general trend of reaffirmation of religion in transitional societies, bearing in mind the importance of Islam in shaping the national identity of Bosniaks. Thereby, based on available sources and literature, interviews with members of the dervish orders and field indicators, the article with special attention points to the theological, ideological and social relation of Sufi's interpretation of Islam to Islamic religious movements with a shorter tradition of presence in Bosnia and Herzegovina, emphasizing the geopolitical dimension of this doctrinal conflict. Finally, based on available data, the article cartographically interprets the traditional presence of Sufism in Bosnia and Herzegovina.
\end{abstract}

Keywords: Islam, Sufism, dervishes, reaffirmation of religion, Bosnia and Herzegovina.

1 Corresponding author: J. Botić, Ministry of Science and Education, Zagreb, Croatia; e-mail: Jurica.Botic@mzo.hr 


\section{Introduction}

In addition to Bosnia and Herzegovina as a multi-ethnic and multi-religious country, it is also a country with an autochthonous European Muslim population. The Islamic affiliation, the multi-century tradition of practicing religion and religious symbolism have significantly influenced the organization of geographic, especially urban space, as well as the formation of the ethnic/national and cultural identity of Bosnian-Herzegovinian Muslims. Due to the Ottoman influence, belonging to the Hanafi madhhab, as one of the four recognized legal schools within Sunni Islam, is the dominant determinant of the BosnianHerzegovinian way of practicing Islam. However, with the official Islamic religious organization and the ulama, within Bosnian-Herzegovinian and even the Balkan Islam in general, there was a strong tradition of Sufism, whose status differed depending on how much the particular dervish order enjoyed sympathy and support from political authorities, but more depending on how much it was in opposition to the ulama mainstream teaching.

With the collapse of communism, there are a reaffirmation of religion and renewal of religious life in transitional countries, and after the decades-long official ban on Sufism and dervish orders, there is a revival of dervish activity in Bosnia and Herzegovina at the end of the $20^{\text {th }}$ century. Emerged among the Bosnian-Herzegovinian Muslims with the renewal of religious life, the interpretative diversities in the religious sense have also led to the question of spreading geopolitical influences from different power centres primarily from the Islamic world. Thus, primarily from the aspect of geography of religion, but also political geography, this paper seeks to present the structural and spatial position of Sufism within Islam in Bosnia and Herzegovina, both in the past and nowadays, and to interpret its influence on (geo)political circumstances in this country.

\section{Theoretical and methodological framework}

As stated initially, identity is undoubtedly an indispensable factor in the study of social geography, so also of political geography and geography of religion as its components. Within contemporary, postmodern settings, the articulation of cultural identity has become an increasingly significant and reflexive process, so also in geography that emphasizes the connectivity of space and identity, although in ever-changing ways, but also a significant role of identity the formation and reproduction of distinctive cultural spaces (Stump, 2008, 372). Religious identity is an indispensable element of the total identity of the population of the Southeast Europe. According to Giddens's definition, religion incorporates a set of symbols, invokes a sense of humility and awe, and these feelings 
and symbols are associated with ceremonies involving a community of believers (Giddens, 2007, 531). Religion can certainly be interpreted as a cultural system, an integrated complex of meanings, symbols, and behaviours articulated by a community of adherents. As cultural systems, religions continually develop in relation to the specific place in which they are articulated and lived by communities of believers (Stump, 2008, 7, 109). Moreover, by set of symbols, they actively participate in the symbolization of space, especially in public places. In addition, the intent of symbolization of space is often to emphasize one's own interpretation of historical circumstances (Zupančič, 2017, 142).

During the $20^{\text {th }}$ century dominant opinion was that secularism would completely suppress the influence of religion. As a result of such an attitude, religion has tended to be marginalized as an area of study within many of the social sciences, including human geography (Stump, 2008, 369). However, the religious revival has questioned an unconditional confidence in secularization in many parts of the World at the end of the $20^{\text {th }}$ century (Flint, Taylor, 2011, 280; Stump, 2008,369 ). Through postmodern values, the globalization has influenced "the secularization of secularism" and the idea that secularism should not be spared from criticism (Bilgili, 2011, 138). Indeed, the secularization theory has by no means proved that modernization necessarily leads to the decline of religiosity, but on the contrary, the World is still extremely religious today. Although in some parts of the world secularization has had more effect than in other, religious communities have found, in a number of cases, a way of survival and even strengthening through the opposition to secularization (Berger, 2008, 12-14). In the case of Islam, secularization not only failed to push out the role of religion in society, but religious regulations have successfully found the way of their own implementation into civic normative acts. However, An-Na'im considers the imposition of sharia by the state to be erroneous, as traditional sharia's formulations are conditioned by the specific experience of specific societies, and hence are necessarily human and secular. On the other hand, as a complete separation of religion and politics as a response to fundamentalist demands, the European model of secularism is not really viable in Muslim societies, as it implies the renunciation of Muslims from their Islamic cultural and religious foundations and the acceptance of philosophical models created through the European experience of Christianity and enlightenment (An-Na'im, 2008, 135-137).

By developing the basic concept of geopolitical culture within the theoretical approach of critical geopolitics, Gearóid Ó Tuathail points out that geopolitical culture stems from the collision of the state with the World and is conditioned by a series of factors: geographic position of the state, historical condition and bureaucratic organization, discourses of national identity and tradition of theorizing relationships with the rest of the World, and the power networks that operate within the state (Ó Tuathail, 2007, 21). Of course, hierarchical order of 
factors affecting the totality of identity is not the same in all societies. For example, the religious identity of Muslims in Bosnia and Herzegovina is a fundamental differentia specifica of national identity of Bosniaks. However, it should also be borne in mind that every self-identification of an individual is multi-layered, so that a Muslim nowadays does not have to define himself solely on the basis of his or her religious identity, but can also be identified as a citizen of a particular country, expert, spouse or parent (An-Na'im, 2008, 125). The construction and transformation of a national identity are also undoubtedly geographic processes, since they are related to certain areas and places, whereby identity is not confined solely to the space of the national state, but extends from the subnational to the supranational framework (Dodds, 2009, 86). Therefore, the so-called "popular geopolitics" is of particular significance in the context of the identity defining by sending geopolitical messages to ordinary people in an informal way through channels that find their expression in the popular culture of the state (Ó Tuathail, 2007, 23).

Based on the aforementioned theoretical framework, two hypotheses are formed for the purpose of this paper. According to the first one, the restoration of dervish life as a traditional element of religious practice of BosnianHerzegovinian Muslims is part of the general trend of reaffirmation of religion of Bosnia and Herzegovina as a transitional country, but exclusively as part of the Islamic mainstream. On the other hand, according to the second hypothesis, the doctrinal conflict within the Bosnian-Herzegovinian Islamic scene is the result of the conflict of geopolitical concepts of their emissive areas.

With the aim of verifying the hypothesis, the historical analysis will present the historical development and presence of various dervish orders in Bosnia and Herzegovina, as well as the spatial distribution of dervish tekkes, depending on the certain order and the urban or rural ambience in which the certain dervish site has been located. Furthermore, the interviews with experts in this scientific question will try to overcome the problem of the lack of literature related to the dervish activity in Bosnia and Herzegovina, especially nowadays, mainly related to the relation of dervish organizations to the official Islamic community in Bosnia and Herzegovina. The method of field indicators has provided a significant contribution to the research process by overcoming the deficiencies of quantitative or sufficiently relevant data, particularly in case of studies dealing with identity issues as is often the case in political geography (Zupančič, 2006, 11-12). In this particular case, observation of the field indicators determines the visibility and presence of dervishes in religious and public life in Bosnia and Herzegovina. Finally, cartographic methods will produce a mapping of the spatial distribution of dervish tekkes in the past and nowadays to determine the observed regularities. 


\section{Sufism and its position within Islam}

The roots of Sufism date back to the time of the Omayyad dynasty as a specific form of asceticism (zuhd) that develops as a reaction to the growing secularity and luxury of the Muslim community. The name originates from the word tasawwuf which means the rough woollen cloaks worn by the poor, and even the prophet Muhammad himself (Armstrong, 2008, 138-139; Smailagić, 1990, 597). Sufis rejected the claims that Sufism represents "other Islam" and emphasized themselves as Muslims following the fundamental teachings of Islam (Ramadan, 1999, 37). This interpretation undoubtedly best corresponds to the time of Sufism emerging in the $9^{\text {th }}$ century in Baghdad and the relation of the first Sufis to the Islamic mainstream (Green, 2012, 16). Nevertheless, the Sufi theology, according to many interpretations prone to mysticism, was often very open to the acceptance of philosophical ideas, love poetry, and even elements of Christian theology, which is why many Islamic orthodox Muslims considered it being heretical (Malcolm, 2011, 201).

The Sufis emphasized the inner experiencing of Islam through love as an ideal over all legal regulations. According to Sufi claims, "renunciation, modesty, submission in exile, asceticism and contemplation are a search for spirituality and harmony" (Ramadan, 2001, 218). Moreover, some of them especially worshiped Jesus as the Sufi ideal, for he preached the gospel of love (Armstrong, 2008, 139-140), and Börklüce Mustafa considered that there were no differences between Christians and Muslims, and that a Muslim who denounced a Christian as an infidel, was an infidel himself (Inalcik, 2003, 267). The great ascetic Rabi'a of Basra in southern Iraq (d. 801) was one of the forerunners of Sufism and had a strong ascetic tendency (Ćehajić, 1986, 10; Green, 2012, 21). In fact, Rabi'a emphasized the God of love instead of seeing God as a strict judge. For the purpose of achieving spiritual unity with God, Sufis develop a special technique of proper and deep breathing, fasting, nightly vigil, and the mantric repetition of Divine Names that are related to God in the Qur'an. In some cases, Sufi spiritual meditations have been transformed into unconstrained ecstasies. For example, Abu Yazid al-Bistami was courting to Allah like to a woman in order to achieve complete unity with God, claiming that he ultimately achieved it. Moreover, Husayn ibn Mansur, better known as al-Hallaj, was killed by the ulama because of proclaiming himself identical to the God (Ana l-Haqq - I am the Truth), although the official reason for his death was actually his interpretation that physical pilgrimage in Makkah was not necessary, since the Hajj could be done in the spirit at the table at home (Armstrong, 2008, 140-141; Ćehajić, 1986, 13-14; Green, 2012, 38-41).

Ali ibn Sina (980-1037), in the West known as Avicenna, one of the greatest scholars of the Islamic world, also studied Sufism, believing that the Sufis expe- 
rienced an experience of divine that went beyond all logical processes of reason (Armstrong, 2008, 148). Abu Hamid al-Ghazali (d. 1111), a great Islamic law expert and a lecturer on the Nizamiyya madrasa in Baghdad, promoted amongst the ulama the practice of contemplative rituals designed by the Sufis, alongside the promotion of the outer rules of the sharia. In his time, the dhikr, the incantation of the Divine Names, shifted from the meditative ritual of the lonely individual to group meditation under the leadership of Pîr, a Sufi teacher, who is often considered as the saint after the death, with holding prayers and dhikr at the tombs (Armstrong, 2008, 156-158). From this time, Islamic cities had a Sufi school (khanaqah), as well as a mosque or a madrasa in which the local pîrs had the lectures. The Sufis formed orders or paths (tariqa) that had a supra-ethnical character, representing therefore an integrating factor in the empire (Armstrong, 2008, 159).

However, the Arabic sources from the $14^{\text {th }}$ century, with amazement, describe the dervish group headed by Barak Baba almost as an unbridled group that does not pay any attention to the prayers and fasting, indicating that the ethnic and cultural differences of the Turkish speaking dervishes also affected the differences in understanding of the religion (Inalcik, 2003, 291-292). Still, at the time of the Ottoman Empire some dervish orders were very successfully positioned on the social and political scene. For example, the Khalwatiyya developed close connections with both the Ottomans sultans and their highest officials, so the grand vizier Sokollu Mehmed Pasha established a grand convent in 1574 in the heart of Istanbul (Green, 2012, 132). The above mentioned confirms that dervishes in the Empire were divided into two groups. The first group consisted of officially acknowledged rows, such as the Naqshbandiyya, the Mawlawiyya, and the Khalwatiyya Order, whose tekkes were supported by the waqf income, which were founded by sultans or other dignitaries. Each order had its own costume and cap and its own ceremony, with some famous sheikh for the patron. The second group consisted of secret orders that held secret ceremonies, and they were often opposition to political order (Inalcik, 2003, 298-299).

Nowadays, Sufism is significantly marked by the trends of individual and private understanding deprived of very strict methods, rules and practices that derive from tradition. Such a kind of spirituality, as a kind of applied Sufism, leads individuals to take control of their own directions, rather than simply leave accept the leadership (Radaman, 2005, 119, 125). However, despite their apolitics in the Western societies, Sufis had a significant political role in the resistance to colonialism in Turkey and the countries of the former Soviet Union. In fact, Sufis, especially the Naqshbandiyya, insisted on the so-called "parallel Islam", thereby retaining the independence of religion in the face of compromises in the form of official Islam accepted by religious dignitaries towards ruling elites (Ramadan, 2005, 233; Stump, 2008, 203). 


\section{Historical development of Sufism in Bosnia and Herzegovina}

The dervishes have contributed greatly to the spread of the Ottoman Empire in the Balkans, and numerous legends about the feat of some sheikhs were transmitted by oral tradition (Inalcik, 2003, 239-295). Of course, with the contribution of the spread of the Empire, Sufis have contributed enormously to the spread of Islam. Indeed, by not-insisting on the fast renunciation of the earlier religious traditions of the converts, the Sufi proselytism was very successful throughout the World (Ćehajić, 1986, 21-22; Stump, 2008, 83-84). Also, Sufis have also made a major contribution to the development of urban life throughout the Ottoman Empire, including the Balkans (Ćehajić, 1986, 5). When establishing the cities, the Ottoman Empire initially raised Muslim religious buildings and schools, and then residential buildings (Bojić, 2001,56). Among the cities in Croatia that developed in Ottoman times, Osijek and Požega reached the highest degree of development (Glamuzina, Fuerst-Bjeliš, 2015, 159). However, it is interesting to point out that the Ottomans did not raise new towns in the area of the Požega Sanjak, but they inhabited the Muslim population in the existing cities where the construction of new buildings gave oriental identity (Hafizović, 2011, 279).

As the waqf destined to accommodate travellers in cities or along distant roads, the zawiyahs had an important role in the dervish activities. These types of Sufis lodges have gradually evolved into influential institutions that served different social needs and religious rituals, as well as proselytizing activities (Stump, 2008, 194). The zawiyahs were founded by the dervish sheikhs on a property they received as a waqf from the rulers to settle their own expenses. By the founding of zawiyahs and tekkes, the Turkish colonization of the conquered countries has spread, since many settlers from Anatolia have established new settlements throughout the Empire, including the Balkans (Inalcik, 2003, 232-233). U In the newly established settlements there were numerous associations of craftsmen that frequently gathered the followers of the same dervish order who solved the disputes within the guild alone without the jurisdiction of the court and according to the rules of tarīqa. Therefore, a guild member expressed obedience to the guild elder, who expressed obedience to the tariqa elder. The sheikh was obedient to the sultan or the caliph, who was obedient to God (Gadžo-Kasumović, 2011, 249).

\section{Sufism in Bosnia and Herzegovina under Ottoman rule}

Much of the archival material related to dervishes in Bosnia and Herzegovina remained unpublished. For example, even 223 manuscripts from the Sinan Tekke in Sarajevo remained unpublished (Malcolm, 2011, 201). However, dervishes have come to the territory of Bosnia and Herzegovina with Ottoman 
invaders. Moreover, as combatants, countless dervishes have died during the Ottoman conquest of Bosnia, such as, for example, Horasani whose grave is in Oglavak near Fojnica (Ćehajić, 1986, 21). After the conquest of new space, the Ottomans immediately began to organize the urban space in the oriental style adapted to the demands and needs of the new dominant religion. During the first 15 years of the reign of Sarajevo, or until 1463, the Ottomans built a mosque, tekke, musafirhana (hostel), hamam (bath), a bridge across Miljacka, a great market, a saray (governor's palace) and urban water supply (Malcolm, 2011, 146). Dervishes had a very important role in the Islamization and development of Bosnian-Herzegovinian cities, and Sarajevo has become a significant Dervish centre with a large number of various țarīqas. The Isak Bey Tekke, the first dervish lodge in Sarajevo, erected before 1463, belonged to the Mawlawiyya țariqa. With accompanying buildings it served as a shelter for the poor Muslims, students, warriors and travellers (Ćehajić, 1986, 28). The second, the Skender Pasha Tekke, erected around 1500, belonged to the Naqshbandiyya Order. The Sinan Pasha Tekke and the Bistrigi Tekke were erected in the $17^{\text {th }}$ century (Čelebi, 1967, 110; Malcolm, 2011, 202, Oruç, 2011, 270-271).

The data from the census from 1550 indicate the existence of dervishes in Banja Luka from the earliest times of Ottoman administration. The existence of the Ahmed Dede zawiyah in the $16^{\text {th }}$ century confirms the dervish contribution to the urban development of the city, and according to some interpretations it belonged to the Bektashi Order (Korić, 2011, 321-324, Oruç, 2011, 275). The dervish contribution to the development of urban life in Bosnia and Herzegovina is also reflected in the example of Zenica, which until the middle of the $16^{\text {th }}$ century retains the characteristics of a rural settlement. However, Zenica starts its more significant urban development by settling groups of traders, craftsmen and dervishes (Oruç, 2011, 272-273). In the example of many towns in Bosnia and Herzegovina we can prove that the dervish presence has been recorded since the beginning of Ottoman administration. For example, in eastern Bosnia, in the place where there was a settlement in the pre-Ottoman period, the Ottomans founded the town of Rogatica where, according to the data from the Defter of 1489, we find evidence of the existence of a zawiyah (Oruç, 2011, 271). However, the tekkes were not just a place of socializing and devotion, but also the centres of the international network. For example, members of the Naqshbandiyya țarīqa have travelled to Central Asia to visit the famous sheikhs (Malcolm, 2011, 202). In addition, the Sufis influenced one more occurrence in the space. Indeed, the cult of saints and prayers on the graves of the sheikhs encouraged the development of the tradition of pilgrimage on locations related to dervish activities (Ćehajić, 1986, 15; Stump, 2008, 245). 


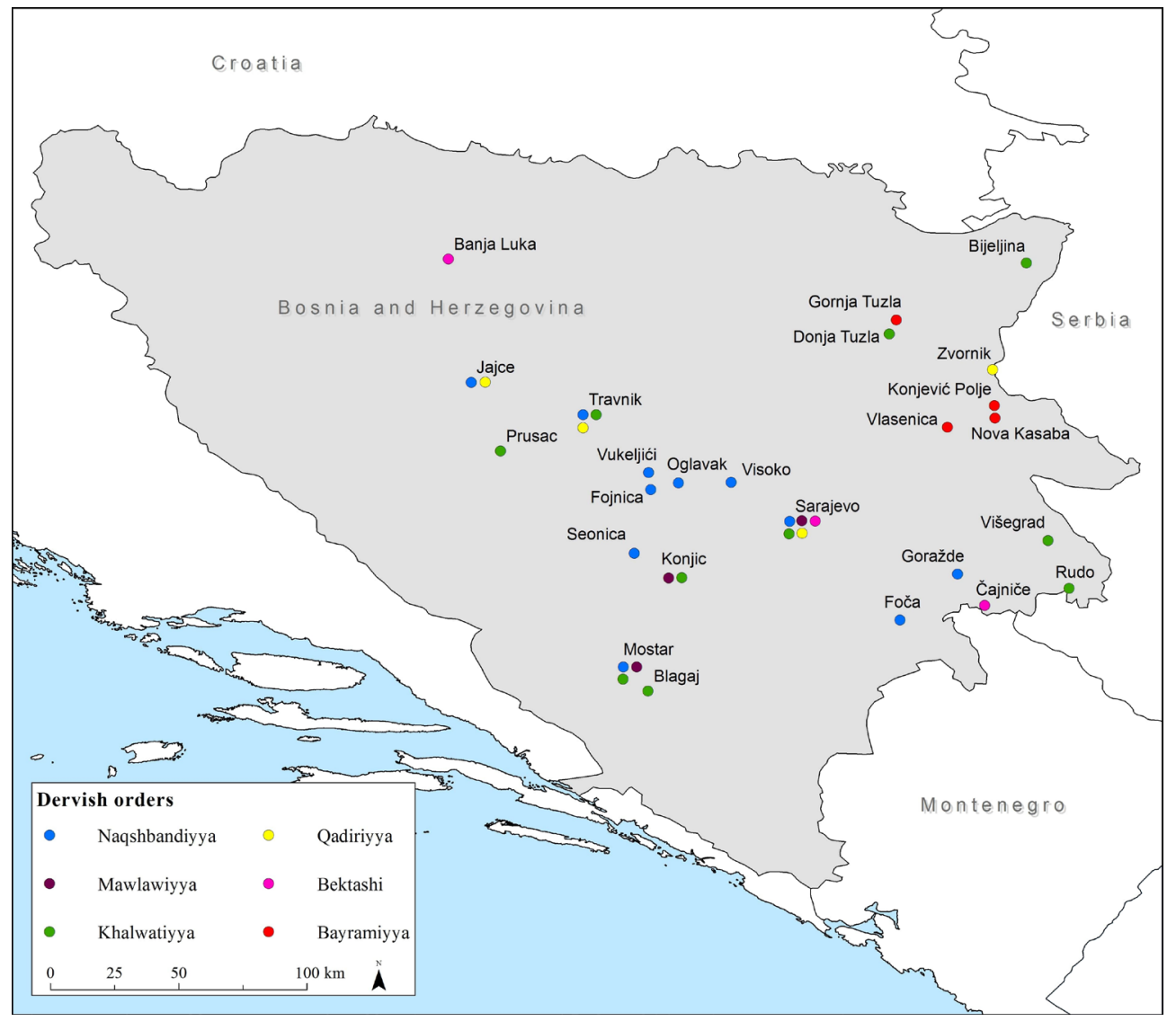

Figure 1. Traditional spatial distribution of leading dervish orders and the most prominent tekkes in Bosnia and Herzegovina (Source: made by the author)

Numerous dervish orders were active in Bosnia and Herzegovina, and the Naqshbandiyya were the most represented (Fig. 1). Muhammad Baha'uddin Uwaysi al-Bukhari, known as Shah Naqshband (d. 1389), was the founder of this extremely orthodox order, whose rituals were based on a voiceless dhikr. However, according to Edin Urjan Kukavica², the Naqshbandiyya-Rifa'iyya sheikh from Sarajevo, the Bosnian-Herzegovinian Naqshbandiyya are famous for the loud dhikr. This order, whose members participated in the battles of Mehmed the Conqueror, has been present in Bosnia and Herzegovina since the $15^{\text {th }}$ century and had the tekkes in Sarajevo, Mostar, Travnik, Jajce, Foča, Goražde, Čajniče, Visoko, Vukeljići (Živčići), Oglavak, Fojnica and Seonica near Konjic 31,2018

2 The author made an interview with Sheikh Edin Urjan Kukavica in Sarajevo on May 
(Ćehajić, 1986, 34-38, 44-65). Numerous tekkes were exalted with their beauty and represented an unavoidable architectural element in the space. Even those outside the urban area, such as the architectural ensemble of Naqshbandiyya Tekke in Živčići in Fojnica region, are listed on the list of national monuments of Bosnia and Herzegovina (Jukić, 2014, 531). As a tekke completely isolated outside the urbanized space, the Oglavak Tekke is of particular significance among the Naqshbandiyya Tekkes. The tekke was founded in the $19^{\text {th }}$ century by Sheikh Abdurrahman Sirriya, the follower of Sheikh Husein Zukić, the chief of Živčići Tekke, and was home to numerous prominent dignitaries of that time, such as Husein Bey Gradaščević and Omer Pasha Latas. Nowadays, the keys of tekke are kept by the Sikirić family, descendants of its founder (Botić, 2017, 109; Ćehajić, 1986, 55-58).

Jalāl ad-Dīn Muhammad Rūmī (1207-1273), the patron saint of the Mawlawiyya Order, who moved as a refugee from his native Khorasan to Konya in Anatolia, initiated the establishment of the order of the turning dervishes dancers who tried to achieve ecstasy by song, dance, poetry and music (Armstrong, 2008, 173-174; Inalcik, 2003, 313-314). The Mawlawiyya began their work in Bosnia and Herzegovina immediately after the Ottoman conquest in the $15^{\text {th }}$ century. They had tekkes in Sarajevo, Mostar and Konjic, and the most famous of them was the Isak Bey Tekke in Sarajevo (Ćehajić, 1986, 28). The name of the Khalwatiyya Order derives from the word khalwah which means "retiring into seclusion and solitude for a certain period of time", and hence means a private conversation of Sufi with God in a space completely separate from humans (Öztürk, 2011, 293). According to sources, the Khalwatiyya in Bosnia and Herzegovina had tekkes in Sarajevo, Travnik, Blagaj, Višegrad, Rudo, Bijeljina, Donja Tuzla, Mostar, Konjic and Prusac (Čelebi, 1967, 132; Ćehajić, 1986, 46, 83-101; Öztürk, 2011, 299). Abd al-Qādir al-Jilānī (10. st.) founded the first recorded tarīqa under the name of al-Qādiriyya (Ramadan, 1999, 37). This orthodox order appears in Bosnia and Herzegovina in the mid$17^{\text {th }}$ century, and it founded the tekkes in Sarajevo, Travnik, Jajce and Zvornik (Ćehajić, 1986, 123).

In spite of the popularity among the Janissaries and the support of tekkes from Albania and Turkey, the Bektashi order has not been strongly rooted in Bosnia and Herzegovina, most probably due to its heterodoxy features. This order had tekkes in Čajniče, Sarajevo and Banja Luka (Ćehajić, 1986, 167-169; Malcolm, 2011, 202-203; Oruç, 2011, 275). However, the Bektashi played a strong role in spreading Islam among other peoples in the Balkans, due to a very tolerant relation to other religions. The popularity of this order among the Janissaries some historians attribute to their mostly Christian origins (Ćehajić, 1986, 166). Moreover, members of this țarīqa have not insisted on strict respect for Islamic rituals such as prayer and fasting, wearing a headscarves for 
women and forbidding them to mix with men, and they were also allowing drinking of wine (Inalcik, 2003, 308-309). The particular feature of the Balkan Bektashi was their retention of elements of Slavic cult and mythology (Ćehajić, 1986, 173). From the less represented orders, we also distinguish the branches of the Bayramiyya Order with tekkes in Orlovići near Vlasenica, Konjević Polje, Nova Kasaba and Gornja Tuzla (Ćehajić, 1986, 191-192, 200-203).

However, with special attention we should observe a tekke built outside the urban space at the site of earlier shrines and used by several orders. In fact, one of the most famous tekkes in Bosnia and Herzegovina is founded on the source of the Buna River (Fig. 2), which emerges from the rock in the area of Blagaj, which was mentioned in the $15^{\text {th }}$ century as a fortification and then as a town with a cave, fortress and its own authority. At the place where, according to the tradition in the $13^{\text {th }}$ century dervish and traveler Sari Saltuk Dede supposedly wanted to rest after death, in 1470 the Bektashi Order raised the first tekke, and with it a blank tomb, cenotaph, as a memorial to this dervish and the teaching of Al-Fatiha. However, after weakening of the Bektashi influence at the end of the $16^{\text {th }}$ century, the Khalwatiyya took over the tekke in Blagaj and remained here until the middle of the $18^{\text {th }}$ century. Under their leadership, especially at the time of Sheikh Ahmet Mujezinović, the tekke experiences new extensions and becomes a centre of learning and nurturing musical tradition, especially in performing of dhikr. In the $19^{\text {th }}$ century, the tekke gained baroque elements thanks to Omer Pasha Latas, who renewed it at the initia-

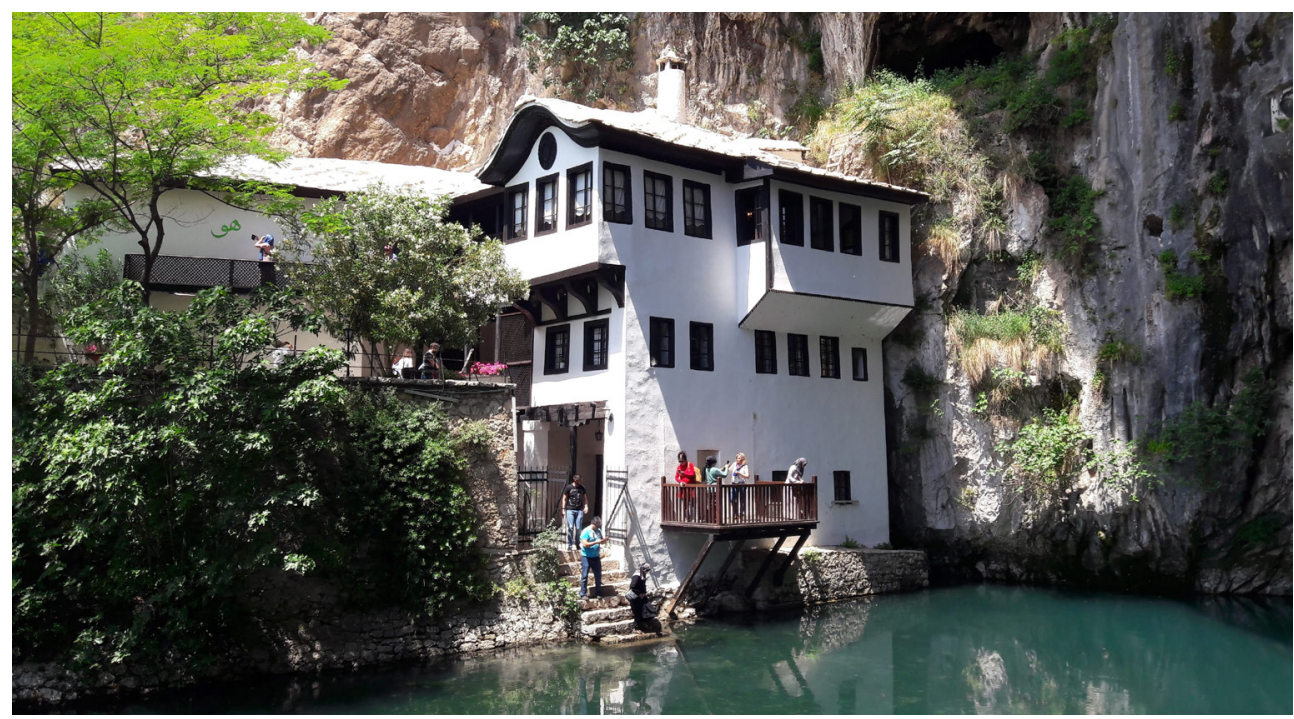

Figure 2. The Blagaj Tekke and the Buna Source in the rock (Source: author) 
tive of Sheikh Muhammad Hindi (Mičijević, 2004, 5, 74-77). However, Sheikh Kukavica points out that Blagaj is not the only example of the construction of the tekke in the place of the earlier sanctuaries, noting the similar examples in Sarajevo and Prusac.

\section{Sufism in Bosnia and Herzegovina from 1878 to 1991}

Prior to the departure of the Ottoman Empire from Bosnia and Herzegovina in the $19^{\text {th }}$ century, Sarajevo and the surrounding area numbered 101 mosques and masjids, 7 madrasas, 9 tekkes and 17 turbahs (McCarthy, 1996, 60). Unlike other parts of the Balkans, after the departure of the Ottoman Empire from Bosnia and Herzegovina and the introduction of the AustroHungarian Administration, the dervishes not only were not suppressed from the historical stage, but continued to act freely and even to found new tekkes (Abiva, 2010, 100). However, due to the large migration of the Muslim population, some dervish orders like the Khalwatiyya have completely disappeared from Bosnia and Herzegovina until the end of the existence of Monarchist Yugoslavia (Abiva, 2010, 100). Moreover, under the guise of the struggle against the "centuries-old backwardness", the Yugoslav communist authorities banned the traditional features of Islamic culture such as the headscarves and the fez, and abolished the Dervish ranks, the madrasas and the courts (Goldstein, 2008, 427; Malcolm, 2011, 341-342; Sarač-Rujanac, 2012, 37-38). The devastation of the old and, for urban development of Sarajevo, significantly important the Mawlawiyya Isak Bey Tekke on Bentbaša, left a big echo in the public (Beglerović, 2011, 429). Nevertheless, in spite of the ban on acting and closure of tekkes, in 1957, Mujaga Merhemić organized the memorial of the death of Mawlānā Jalāl ad-Dīn Muhammad Rūmī (Halilagić, 2011, 472). The prohibition and the abolition of dervish orders unfavourably affected the state of tekkes and the entire cultural heritage related to dervishes. For example, in the socialist Yugoslavia, the state decided to take care over the Blagaj Tekke, but after the fall of the rock in 1974, only the walls were left (Mičijević, 2004, 77-78).

Despite the efforts of the official politics of socialist Yugoslavia, in the early 1980s the Bosnian-Herzegovinian Muslims were not isolated from the influence of the re-Islamization processes of the Islamic world, including the Islamic Revolution in Iran. For example, agents of the Yugoslav State Security Service found Iran's propaganda materials and images of Ayatollah Khomeini in Gazi Husrev Bey Madrasa in Sarajevo (Sarač-Rujanac, 2012, 30, 123). The restoration of Sufi activity in Socialist Yugoslavia began in 1974 by founding of the Community of Islamic Dervish Orders of Yugoslavia (ZIDRA) (Abiva, $2010,100)$. As the first manifestation after thirty years of prohibition of dervish orders, the Mawlid by the Buna River in 1981 caused the great attention and 
displeasure of the political authorities. This event points to not only the empowerment of the Islamic community, but also the significant changes in the entire Yugoslav society (Sarač-Rujanac, 2012, 118).

\section{Sufism and reaffirmation of religion in contemporary Bosnia and Herzegovina}

The former Grand Mufti (Raisu-l-ulama) Mustafa Cerić emphasizes the crucial importance of Islam in defining the national identity of Bosniaks, noting that Islamic tradition is the basis of the identity of the Bosniak people, and that the Bosniaks are without Islam, without Islamic civilization and without Islamic culture are nothing (Schindler, 2011, 83). The Concert of Islamic Spiritual Music, held in March 1990 in Sarajevo's Zetra Hall, to over twenty thousand visitors from Bosnia and Herzegovina and Sandžak, is a special example of not only public manifestation of the restoration of Islamic religious life, but also of intense interweaving of religious and national content in the construction of a modern Bosniak identity (Filandra, 2012, 56). In the context of the contemporary ethno-religious symbolization of the space in Bosnia and Herzegovina, Šaćir Filandra warns of the emergence of "mosque kiosks" as a danger of "distorting the complete system of Islamic symbolism" which "threatens to become a metaphor of the non-selective and inappropriate use of Islamic symbols in times and places that have nothing to do with Islam (Filandra, 2012, 396).

However, the restored and newly built tekkes provide a powerful basis for the development of Islamic spirituality, but also for the national identity of Bosniaks, taking on an important place in the ethno-symbolization of space their its oriental visual identity. The Naqshbandiyya tekke on Mejtaš is considered the most active tekke in Bosnia and Herzegovina, also noticed by the famous National Geographic (Botić, 2017, 108). Probably the largest tekke in the Balkans is open in Kaćuni in Central Bosnia (Abiva, 2010, 100). Sheikh Kukavica notes that contemporary tekkes are mostly found in urban areas, but also outside them. Nowadays, there are the Naqshbandiyya, the Rifa'iyya, the Qādiriyya and the Khalwatiyya tekkes all over Bosnia and Herzegovina, in Sarajevo, Olovo, Kaćuni near Busovača, Radinovići near Visoko, Stolac, Blagaj and others, but also among the Bosniak diaspora. All previously mentioned indicates that the restoration of religious life in Bosnia and Herzegovina has beneficial effected on the restoration of the dervish activity which has proved to be part of Islamic tradition in this country. However, it is indicative that the Naqshbandiyya are again the most numerous and most active dervish order in Bosnia and Herzegovina, confirming the hypothesis that the restora- 
tion of dervish life as a traditional element of religious practice of BosnianHerzegovinian Muslims is part of the general trend of reaffirmation of religion of Bosnia and Herzegovina as a transitional country, but exclusively as part of the Islamic mainstream.

Finally, the needs of modern people open up numerous other opportunities for valorisation of tekkes as the cultural heritage of Bosnia and Herzegovina. Although Islamic pilgrimage is primarily related to compulsory pilgrimage in Mecca in Saudi Arabia, Islamic religious objects, as well as dervish tekkes, traditions and customs associated with them, represent an unquestioning potential for tourism valorisation, both in terms of Islamic religious tourism and tourism in general. In addition to the Blagaj Tekke, as the most visited locality related to the dervishes in Bosnia and Herzegovina, the manifestation at traditional prayer site of Ajvatovica near Prusac is an increasingly interesting in a tourist sense, together with cherishing memories of Ajvaz Dede, who prayed for God's help in enabling the construction of a water supply for Prusac (Botić, 2017, 106-112).

\section{Geopolitical reflections of the reaffirmation of Sufism in Bosnia and Herzegovina}

For Alija Izetbegović, the first president of independent Bosnia and Herzegovina, the return to Islam means the return of power and reputation, and hence emphasizes that "Turkey as the Islamic country ruled the world", while "Turkey as a European plagiarism", apparently as a secular state, "represents a third-rate country, like a hundred more in the world" (Izetbegović, 1970, 3). However, Izetbegović's remark less and less describes contemporary Turkey, which is increasingly trying to impose itself as a powerful geopolitical factor of wider regional significance according to the doctrine named Neo-Ottomanism by critics. Tanasković defines Neo-Ottomanism as a "the complex macro-ideological platform by which today's Turkey, as its legitimate civilizational successor, should reaffirm the overall spiritual, cultural and political heritage of the Ottoman Empire, and therefore, within the redistribution of global power and influence, which is in progress, ensure and effectively play the role of one of the World's major international factors" (Tanasković, 2010, 8). Within the aforementioned, the Balkans has a particularly important position in Turkish geopolitics, so the former Prime Minister Ahmet Davutoğlu states that Muslim communities in the Balkans, as the inheritors of the Ottoman Empire, are the basis of Turkey's political influence in the Balkans (Davutoğlu, 2014, 134).

Turkish Cooperation and Coordination Agency (TIKA) has made a major contribution to the reconstruction of Islamic religious buildings in Bosnia and Herzegovina, including tekkes. This agency was founded in 1992 at the time of Turkish President Özal with the aim of providing various forms of assis- 
tance and expansion of Turkish influence beyond its own borders (Tanasković, 2010,31 . This form of aid can be quite reasonably be observed in the context of the theoretical approach to critical geopolitics as a Turkish example of the confirmation of the theories of cultural and popular geopolitics. Indeed, the method of field indicators, used to conduct field research on several dervish sites, confirmed that TIKA was involved in the reconstruction of almost all of the mentioned sites, including the Mawlawiyya tekke in Sarajevo (Fig. 3), as well as landscaping at the Ajvatovica site, where folklore societies from Turkey participate in the traditional manifestation (Botić, 2017, 108-112). Moreover, Davutoğlu recognizes that every demolished mosque, or, in the cultural sense, every destroyed factor of the Ottoman tradition in the Balkans represents one cornerstone removed from the cross-border influence of Turkey in this area (Davutoğlu, 2014, 75).

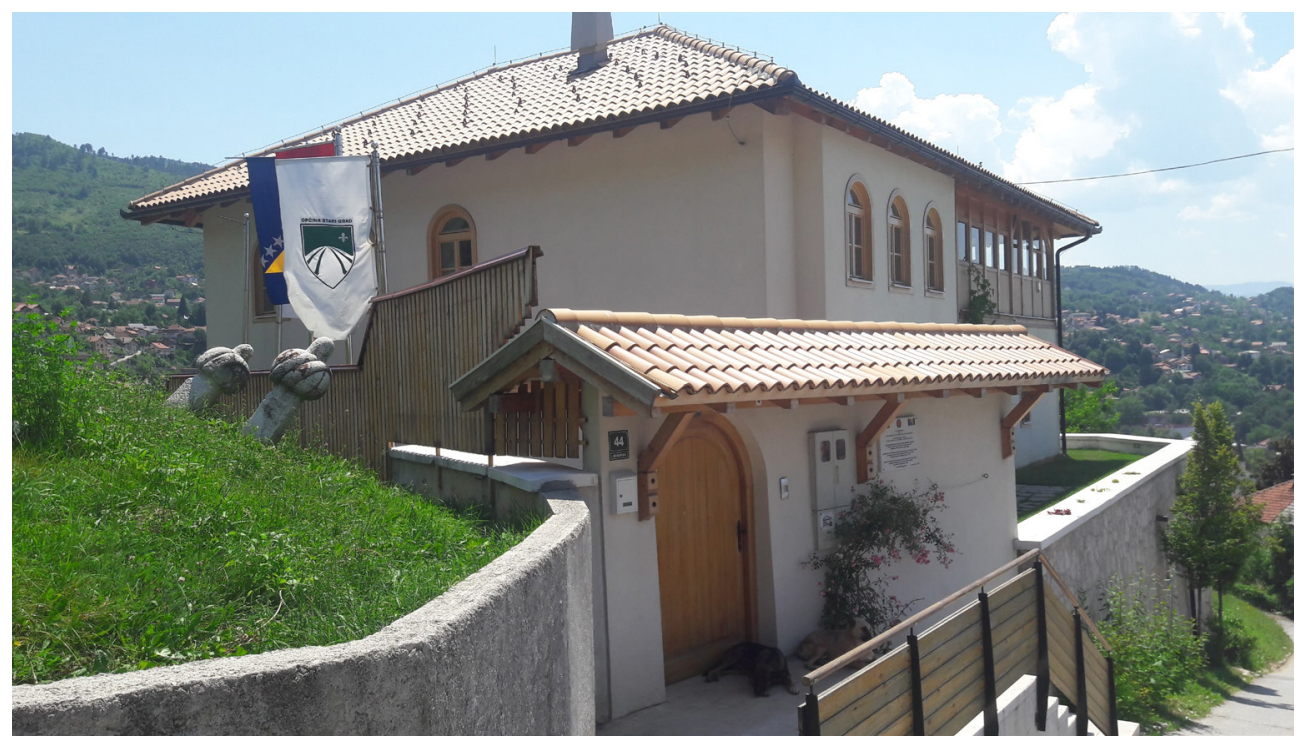

Figure 3. The Mawlawiyya tekke by the Yellow Fortress in Sarajevo (Source: Botić, 2017, 108)

According to its Constitution, last revised in 1997, the Islamic Community in Bosnia and Herzegovina is obliged to protect the authenticity of Islamic norms and to ensure their interpretation and application. Thereby, the jurisdiction of Riyasat of $\mathrm{BiH}$ includes the entire area inhabited by Muslims, who declare themselves Bosniaks in the ethnic sense, including Muslim communities in neighbouring states. Due to the interpretative attachment of this umbrella religious institution of Bosnia and Herzegovina to the Hanafi madhhab, tradi- 
tionally present in the Balkans since Islam's arrival at the time of the Ottoman Empire, the official religious interpretation of the Islamic Community in $\mathrm{BiH}$ is compatible with the interpretations practiced in Turkey. As part of such an Islamic community since 2002, dervishes exist within the Tariqa Centre as a parallel organization, whereby, according to Sheik Kukavica, the interest in dervishes is growing rapidly among Bosnian-Herzegovinian Muslims. However, followers of the Salafi movement in this country, which operates under great influence and the patronage of organizations from the Arab world, question the interpretative authority of the Islamic Community of Bosnia and Herzegovina (Botić, 2017, 112-113; Sarajlić, 2011, 76-81). Salafis follow the conservative teaching of Muhammad ibn Abd al-Wahhab from the $18^{\text {th }}$ century and are recognizable by the specific clothes, beards and strictly prescribed patterns of behaviour (Potežica, 2007, 39-40, 57-58; Trifunović, Stojaković, Vračar, 2011, 60-61, 71-72). Nevertheless, the Salafi movement in Bosnia and Herzegovina is not unique, and differences are based on the relation to the Islamic Community in Bosnia and Herzegovina, terrorism and global jihad (Azinović, 2012, 150-152).

On the other hand, the Fatwa of the Riyasat of the Islamic Community of Bosnia and Herzegovina in 1993, which for Islamic religious officials prescribes an obligation to adhere to Hanafi legal school, represents a sort of attempt to prevent the possibility of dividing Bosnian-Herzegovinian Muslims into interpretative sense resulting in divisions within the whole Bosniak national corps, since "the Bosnian Wahhabis do not realize that the unity of Bosniaks and Muslims, meaning people and believers, is supported and ensured through the unique madhhab" (Filandra, 2012, 412-414). In fact, the influence of the Salafi movement widened considerably during the war, while, although unwilling to the interpretation of Islam brought by foreign warriors, a part of Bosniaks gradually accepted the Salafis because of their contribution and the strong will to participate in the war against the enemy (Azinović, 2012, 40-41; Kohlmann, 2005, 81, 127; Schindler, 2011, 102). Sheikh Kukavica therefore emphasizes that it is not possible to speak about "the unique or even the common Muslim identity of Bosnian Muslims" and warns that "within the Bosniak national corps there are very strong and influential groups and individuals who insist on: 1. Pan-Bosniakism as a pandan and legitimate successor to former Panislamism, 2. a unique identification of all Muslims of the former Yugoslavia (except Kosovo Albanians) as Bosniaks, and 3. the identification of imported, non-authentic, for Bosniak traditional mind completely foreign aspects of nationalism concealed as pure (recently Sunni) Islam with the true Bosniakism" (Kukavica, 2018, 61-62).

According to Salafi interpretations, the following rituals associated with Sufis represent deviations from the correct practice of Islam's pious forebears 
(al-salaf): the celebration of the Prophet's birthday (mawlid); recitations od Sufi poetry and Sufi chants (dhikr) accompanied by drumbeat and dances; celebrations of birthdays of Sufi sheikhs and scholars; seeking the blessing (baraka) of "holy" sites, monuments, dead and living individuals, or their photographs; the construction of buildings and monuments over the graves of religious scholars and Sufis and the practice of converting them into mosques etc. (Knysh, 2017, 185). The Salafis consider many traditions and elements of traditional Islamic practice in Bosnia and Herzegovina, including those closely related to dervish rituals, such as mawlid, the common dhikr after prayer, the prayer sites and the tombs (türbe), as novelties. For example, on the posters for the 500th anniversary of Ajvatovica in 2009, the Salafis wrote the word shirk, meaning unfaithfulness, considering that "organizing Ajvatovica as well as participating in it is not allowed by Islam". A year later, opponents of pilgrimage on Ajvatovica carried out an explosive terrorist attack on the Bugojno police station, whereby one person died (Filandra, 2012, 436). These events confirm the obvious dichotomy within the Muslim corps in Bosnia and Herzegovina and a sort of struggle for supremacy in the interpretative sense. Moreover, lobbying and financial support from foreign centres of power, which is also often manifested in the competition in the symbolization of space in the form of domination in the style of religious buildings, point to the struggle for the dominance of the geopolitical concepts of these centres of power. These processes confirm the other hypothesis of this article.

\section{Conclusion}

The roots of Sufism have been found since the earliest periods of spreading Islam in Bosnia and Herzegovina, and numerous dervishes directly participated in the invasion of the Ottoman army. Furthermore, dervishes have made a strong contribution to the development of the urban life, and dervish tekkes have been an inevitable element of mostly urban and often rural settlements in Ottoman Bosnia and Herzegovina. Although in very specific relations with the official ulema, the dominant orders in Bosnia and Herzegovina generally correspond to the mainstream stances of official Islamic authorities, so it is not surprising that the Naqshbandiyya tariqa is traditionally the most prominent dervish order in this country, unlike the heterodox Bektashi order.

As a part of the general trend of reaffirmation of the religion and desecularization of transition societies at the end of the $20^{\text {th }}$ and beginning of the $21^{\text {st }}$ century, in Bosnia and Herzegovina there is a renewal of religious life and thus of Islam as an important element in shaping the national identity of Bosniaks. The renewal of dervish life as a traditional element of reli- 
gious practice of Bosnian-Herzegovinian Muslims is manifested as a part of the Islamic mainstream and, unlike the past, as part of the official institutions of the Islamic Community in Bosnia and Herzegovina. However, the pluralism of religious interpretations, especially interpretations that deviate from the Bosnian-Herzegovinian tradition, has resulted in more or less apparent doctrinal clash within Bosnian-Herzegovinian Islamic scene, which is largely a result of clashes between geopolitical concepts of interest circles that are recognized as patrons of some of the above-mentioned interpretations.

\section{References}

Abiva, H. (2010). Kratak pregled sufizma na Balkanu. Behar, 93/94(19), 96-101.

An-Na'im, A.A. (2008). Politički islam u nacionalnoj politici i međunarodnim odnosima. In: Weigel, G. et al. (ed.), Desekularizacija sveta: oživljavanje religije i svetska politika (pp. 119-139). Novi Sad: Mediterran Publishing.

Armstrong, K. (2008). Islam: kratka povijest. Zagreb: Alfa.

Azinović, V. (2012). Uvod u studije terorizma. Sarajevo: Fakultet političkih nauka.

Beglerović, S. (2011). Fejzulah-efendija Hadžibajrić kao mevlevijski šejh i mesnevihan u period nakon rušenja Isa-begove tekije. In: Mjesto i uloga derviških redova u Bosni i Hercegovini: zbornik radova povodom obilježavanja 800 godina od rođenja Dželaluddina Rumija (pp. 415-456). Sarajevo: Orijentalni institut: Naučnoistraživački institut "Ibn Sina“.

Berger, P.L. (2008). Desekularizacija sveta: opšti pregled. In: Weigel, G. et al. (ed.), Desekularizacija sveta: oživljavanje religije i svetska politika (pp. 11-30). Novi Sad: Mediterran Publishing.

Bilgili, A. (2011). Post-Secular Society and the Multi-Vocal Religious Sphere in Turkey. European Perpectives: Journal on European Perspectives of the Western Balkans, 3(2), 131-146.

Bojić, M. (2001). Historija Bosne i Bošnjaka (VII-XX vijek). Sarajevo: Šahinpašić.

Botić, J. (2017). Sigurnosni izazovi i potencijali razvoja islamskog vjerskog turizma u Bosni i Hercegovini. Zbornik radova Veleučilišta u Šibeniku: Zbornik radova 3. međunarodne znanstveno-stručne konferencije "Izazove današnjice: održivi obalni i pomorski turizam", 11(5), 104-116.

Čelebi, E. (1967). Putopis: odlomci o jugoslavenskim zemljama. Sarajevo: Svjetlost.

Ćehajić, Dž. (1986). Derviški redovi u jugoslovenskim zemljama s posebnim osvrtom na Bosnu i Hercegovinu. Sarajevo: Orijentalni institut.

Davutoğlu, A. (2014). Strategijska dubina: međunarodni položaj Turske. Beograd: Službeni glasnik. 
Dodds, K. (2009). Geopolitika. Sarajevo, Zagreb: Šahinpašić.

Filandra, Š. (2012). Bošnjacinakon socijalizma:obošnjačkomidentitetu upostjugoslavenskom dobu. Sarajevo: BFZ Preporod: Synopsis.

Flint, C. \& Taylor, P. (2011). Political Geography: World-Economy, Nation-State and Locality ( ${ }^{\text {th }}$ Ed.). London, New York: Routledge.

Gadžo-Kasumović, A. (2011). Esnaf i tarikat. In: Mjesto i uloga derviških redova u Bosni i Hercegovini: zbornik radova povodom obilježavanja 800 godina od rođenja Dželaluddina Rumija (pp. 241-255). Sarajevo: Orijentalni institut: Naučnoistraživački institut "Ibn Sina“.

Giddens, A. (2007). Sociologija. Zagreb: Nakladni zavod Globus.

Glamuzina, N. \& Fuerst-Bjeliš, N. (2015). Historijska geografija Hrvatske. Split: Sveučilište u Splitu: Filozofski fakultet.

Goldstein, I. (2008). Hrvatska 1918-2008. Zagreb: EPH Liber.

Green, N. (2012). Sufism: a global history. Chichester: Wiley-Blackwell.

Hafizović, F. (2011). Slavonija - pitanje uloge derviša u širenju islama. In: Mjesto $i$ uloga derviških redova u Bosni i Hercegovini: zbornik radova povodom obilježavanja 800 godina od rođenja Dželaluddina Rumija (pp. 277-283). Sarajevo: Orijentalni institut: Naučnoistraživački institut "Ibn Sina“.

Halilović, S. (2011). Obilježavanje Šeri arusa u Bosni i Hercegovini. In: Mjesto i uloga derviških redova u Bosni i Hercegovini: zbornik radova povodom obilježavanja 800 godina od rođenja Dželaluddina Rumija (pp. 471-476). Sarajevo: Orijentalni institut: Naučnoistraživački institut "Ibn Sina“.

Inalcik, H. (2003). Osmansko Carstvo: Klasično doba 1300.-1600. Beograd: Utopija.

Izetbegović, A. (1970). Islamska deklaracija: Jedan program islamizacije Muslimana $i$ muslimanskih naroda. URL: http://www.vakat.me/wp-content/ uploads/2017/01/Islamska-Deklaracija-knjiga-o-islamizaciji-muslimana-AlijaIzetbegovic.pdf (07/06/2018).

Jukić, M. (2014). Potencijali i determinante kompleksne turističke ponude Fojničkog kraja. In Zbornik radova Trećeg kongresa geografa Bosne i Hercegovine: Tuzla, 08.10.10.10.2012. (pp. 527-545). Sarajevo: Geografsko društvo u Federaciji Bosne i Hercegovine.

Knish, A. (2017). The Sufism: a new history of Islamic mysticism. Princeton, Oxford: Princeton University Press.

Kohlmann, E.F. (2005). Al-Qa'idin džihad u Europi: afganistansko-bosanska mreža. Zagreb: Naklada Ljevak.

Korić, E. (2011). Uloga zavije Ahmed-dede u razvoju kasabe Banje Luke. In: Mjesto $i$ uloga derviških redova u Bosni i Hercegovini: zbornik radova povodom obilježavanja 800 godina od rođenja Dželaluddina Rumija (pp. 319-325). Sarajevo: Orijentalni institut: Naučnoistraživački institut „Ibn Sina“. 
Kukavica, E.U. (2018). Priručnik za revoluciju: dekonstrukcija etnonacionalističkog narativa u BiH kao uvjet za promjenu političke paradigme: (zajedničkim vrijednostima ka pozitionoj kolektionoj identifikaciji), 1, Sarajevo: autor.

Malcolm, N. (2011). Bosna: kratka povijest. Sarajevo: Buybook.

McCarthy, J. (1996). Ottoman Bosnia, 1800-1878. In: Pinson, M. (Ed.), The Muslims of Bosnia-Herzegovina: Their Historic Development from the Middle Ages to the Dissolution of Yugoslavia (pp. 84-128). Cambridge: Harvard University Press.

Mičijević, S. (2004). Blagaj. Mostar: Slovo.

Ó Tuathail, G. (2007). Uvod: Kritičko promišljanje o geopolitici. In: Ó Tuathail, G.; Dalby, S. \& Routledge, P. (ed.), Uvod u geopolitiku (pp. 15-28). Zagreb: Politička kultura.

Oruç, H. (2011). Uloga tekija u nastanku i razvitku gradova u Bosni. Mjesto i uloga derviških redova u Bosni i Hercegovini: zbornik radova povodom obilježavanja 800 godina od rođenja Dželaluddina Rumija (pp. 267-276). Sarajevo: Orijentalni institut: Naučnoistraživački institut „Ibn Sina“.

Öztürk, M.C. (2011). The Khalwati Order and some Khalwati tekkes in Bosnia. In: Mjesto i uloga derviških redova u Bosni i Hercegovini: zbornik radova povodom obilježavanja 800 godina od rođenja Dželaluddina Rumija (pp. 293-303). Sarajevo: Orijentalni institut: Naučnoistraživački institut „Ibn Sina“.

Potežica, O. (2007). Vehabije: između istine i predrasuda. Beograd: Filip Višnjić.

Ramadan, T. (2001). Islam, the West and the Challenges of Modernity. Leicester: Islamic Foundation.

Ramadan, T. (1999). To be a European Muslim: A Study of Islamic Sources in the European Context. Leicester: Islamic Foundation.

Ramadan, T. (2005). Western Muslims and the Future of Islam. Oxford, New York: Oxford University Press.

Sarajlić, E. (2011). Islamic agents and network politics in post-Dayton Bosnia and Herzegovina. Democracy and Security in Southeastern Europe, 2(6/7), 74-85.

Sarač-Rujanac, Dž. (2012). Odnos vjerskog i nacionalnog u identitetu Bošnjaka od 1980. do 1990. godine. Sarajevo: Institut za istoriju.

Schindler, J.R. (2011). Bosanski rat i terror: Bosna, Al Kaida i uspon globalnog džihada. Beograd: Službeni glasnik.

Smailagić, N. (1990). Leksikon Islama. Sarajevo: Svjetlost.

Stump, R.W. (2008). The geography of religion: faith, place and space. Lanham: Rowman \& Littlefield Publishers.

Tanasković, D. (2010). Neoosmanizam: doktrina i spoljnopolitička praksa. Beograd: Službeni glasnik: Službeni glasnik Republike Srpske.

Trifunović, D.; Stojaković, G. \& Vračar, M. (2011). Terorizam i vehabizam. Beograd: Filip Višnjić. 
Zupančič, J. (2017). Socialna geografija: človek, prostor in čas. Ljubljana: Znanstvena založba Filozofske fakultete.

Zupančič, J. (2006). Terenski indikatorji kot raziskovalna metoda v socialni in politični geografiji. Dela, 25, 7-14. 